\title{
Vicious Desire: The Insect Woman of Kim Kiyoung and Imamura Shōhei
}

Chungkang Kim*

Let's begin with some images from the films of Kim Kiyoung (19191998) and Imamura Shōhei (1926-2006): animals such as rats, cats, squirrels, pigs, insects, and mostly images of women. [Image 1] As these images show, Kim Kiyoung and Imamura Shōhei are both known as eccentric art house directors with women (that is, gender and sexuality), animals, and the primitive aspects of human beings at the heart of their films. While Imamura was recognized in the West and won the grand prize at the Cannes Film Festival in 1983 for Narayama bushiko (The Ballad of Narayama), Kim Kiyoung was (re)discovered in the mid-1990s through a retrospective at the $2^{\text {nd }}$ Busan Film Festival. Naturally, Imamura's work has been widely discussed both academically and journalistically. In contrast, although Kim Kiyoung was a very popular film director from the late 1950s to 1970 in South Korea, he was not well known in the West before he was discovered in the 1990s. This might have been due to the marginality of South Korea during the 1960s and 70s in world film history. During the same period, Japanese cinema had become accepted as 'art,' mostly through positive recognition in Western critical media such as Cahiers du Cinéma. But as soon as Kim was introduced to the West via various venues like the Berlin film festival, many film critics pointed out the similarities of his work to those of such Western directors as Douglas

* Associate Professor, Department of Theater and Film, Hanyang University 

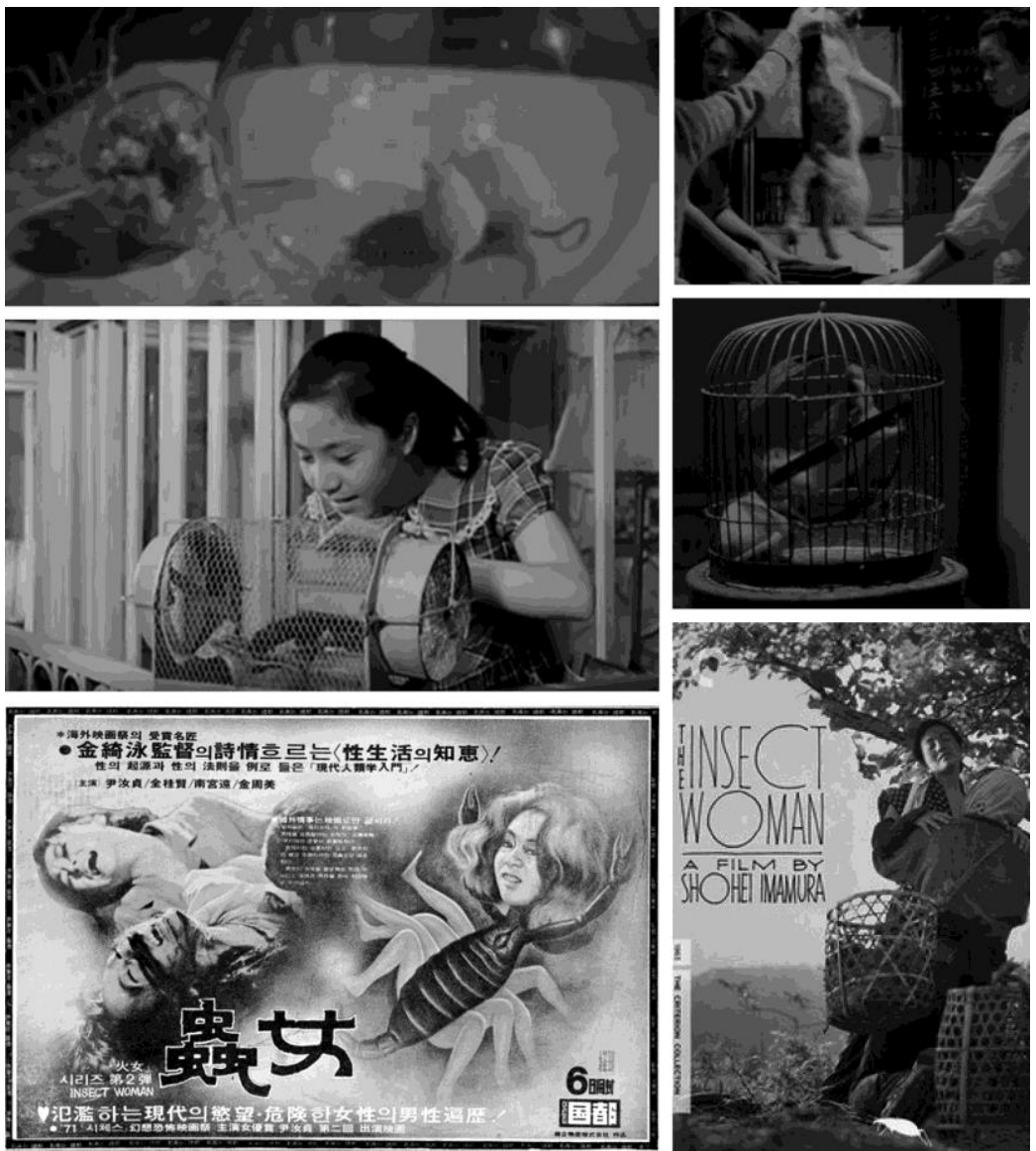

Image 1. Images on the left hand side are from Kim Kiyoung's film and poster. Images on the right hand side are from Imamura Shohei's film and poster.

Sirk and Rainer Werner Fassbinder. ${ }^{1}$

It is notable that Kim's status as a cult director in the 1990's coincided with a particular moment in South Korean history. It was when South

1 Kim Soyoung [Kim Soyŏng], Kundaesŏng ŭi yuryŏngdŭl [Ghost of the Modernity], (Seoul: Ssiat ǔl ppurinŭn saramdŭl, 2000), 87. 
Korea just emerged from the long thirty years of military dictatorship, which created a space for a democratic social atmosphere, the feminist movement, and popular culture. In particular, women's films or films about women's issues began to be highlighted. Kim's films were rediscovered in precisely this context because many of his films deal with "woman" (represented in his titles by the Chinese character 'nyŏ/yŏ,' 女) in a complex tone. ${ }^{2}$ My primary concern is how Kim Kiyoung dealt with women in his film, which was far removed from many sexually exploitive erotic Korean films mass-produced in the 1980s. More interestingly, women in Kim Kiyoung's films share many characteristics with those appearing in Imamura Shōhei's films, in comparison to other South Korean films. While these two directors now stand as representatives of certain types of national auteurs in Korea and Japan, they exhibit in their respective ways significant degrees of transnationality, intercultural engagement and iconic adaption, which I believe emerged from their critical engagement with the imperial culture of Japan before 1945. Despite apparent differences in their life and work, and the seemingly apparent absence of formal cultural relationships between Korea and Japan from 1945 to 1998, the strange similarities between Kim and Imamura alert their viewers to what lies behind their shared eccentricity.

In Cinema and Experience, Miriam Hansen strives to describe "how film and the cinema experience relate to the ongoing, generationally marked reconfiguration of experience in daily life and social relations in labor, the economy and politics," and "how to engage a living thought that is no longer historically current." 3 By rereading many influential philosophers of visuality and film such as Kracauer, Benjamin and Adorno, who were confronting the earliest cinematic culture in the West, she arduously attempts to decipher the "technologically mediated experience

2 Kim Soyoung, Kundaesŏng ŭi yuryŏngdŭl, 158-159.

3 Miriam Hansen, Cinema and Experience: Siegfried Kracauer, Walter Benjamin, and Theodor W. Adorno, (Berkeley and Los Angeles, California: University of California Press, 2012). 
of modern society" globally and locally through cinema and how the cinema experience keenly intersects with a viewing public's lived experience. Though Hansen's discussion does not mention the cinema of East Asia, it critically highlights modern experiences - the acts of expressing and engaging with their own time. But this does not mean that East Asian peoples have plunged into the raging torrents of universal modernity. Different experiences in colonial and imperial cultures might have given rise to the similar yet different reconfigurations of East Asian modernity in their works. Through this particular modernity, East Asians realize their own asymmetrical relationship with the West (or Japan in the Korean case), as Rey Chow noted, a moment possibly experienced as the exhilarating lure of dominant power through the cinematic medium. ${ }^{4}$ The astonishing similarities between the works of Kim Kiyoung and Imamura Shōhei illuminate the shared modern cinema experience within the Japanese Empire, though their life trajectories became divergent when the Japanese empire collapsed.

This paper focuses on The Insect Woman directed by Kim Kiyoung (1972) and Imamura Shōhei (1963), the two distinct films which happen to have the same English-language title and share many similarities. It is not clear to this author why Imamura's Japanese title, Nihon konchŭki (日 本昆蟲記) was translated as “The Insect Woman” when the literal translation is "Entomological Chronicles of Japan." But when Kim Kiyoung's Ch'ungnyŏ (蟲女/충녀) came out a decade later in 1972, it was not difficult to connect the film to Imamura's The Insect Woman. Even though Kim's film was not a direct adaptation of Imamura's, it is acknowledged that many similarities are found between the films of Kim Kiyoung and Imamura Shōhei. For instance, Kim's Koryöjang (1963) and Imamura's Ballads of Narayama (Narayama bushiko,1980) are sometimes compared though it seems that Kim's Koryojang drew more from Kinoshita Keisuke's Narayama bushiko, made in 1958. Regarding these similarities, Yi

4 Rey Chow, Primitive Passions: Visuality, Sexuality, Ethnography, and Contemporary Chinese Cinema (New York: Columbia University Press, 1995). 
Hyoin argues that Kim Kiyoung's experience during the Japanese colonial era (1910-1945) had a great impact on the formation of his eccentricities among his cinematic output in post-colonial Korea. ${ }^{5}$ In a more recent work, Ahn Minhwa compared the Japanese film, The Isolated Zone (Shinkū chitai, 1952), and Kim Kiyoung's The Sea Knows (Hyŏnhaet'an $\breve{u n}$ algoitta, 1961), and concluded that both films evince "colonial difference" (singminjichŏk ch'ai] in the sense that they function to criticize the suppressed imperial/fascist memory of the Japanese Empire in each nation's post-colonial and post-war context. She also identifies "colonial difference" between Japan and Korea that resulted from the different historical situation: Korea under military dictatorship and Japan under the American occupation. ${ }^{6}$ While Ahn's point about each film's role as a social critique of its respective nation (South Korea and Japan) is plausible, this interpretation does not explain Kim Kiyoung's continuing admiration, desires, and even "mimicry"7 of Japanese imperial culture, whether it is conscious or unconscious, even after the fall of the Japanese empire.

Against the tendency to render these two art house directors' work as exceptions to the temporal modality through which they operated, I will read their films as products of a transnational historical time, existing at the crossroads of modernity, ideological normalcy, and its deviation in East Asia. Women on the screen have always served as emblems of modernity, but regarding these two directors' respective The Insect Woman films, I pay particular attention to both global (imperial) and local con-

5 Yi Hyoin, Hanyŏ tŭl pong'gihada [Revolt of the Handmaiden] (Hanŭl are, 2002), 14-25.

6 Ahn Minhwa, "Kim Kiyoung yŏnghwa tŭl esŏ ŭi singminjijŏk ch'ai [Colonial Difference in Kim Kiyoung's film]," in Han'guk yŏnghwa, sekye wa majuch 'ida, ed. Kimsoyoung. [Korean Cinema Meets the World] (Hyŏnsil munhwa, 2018).

7 I use this term, "mimicry" in Homi Bhabha's sense, which is the colonial people's cultural practice that imitates imperial culture, and yet its difference from the origin is reminiscent of the colonial people's subjectivity in a post-colonial situation. See Homi Bhabha, Location of Culture (New York: Routledge, 2004), 121-131. 
texts, and explore how such geopolitical cultural locations of each director could create such similar but different films in South Korea and Japan. By carefully juxtaposing these two films, while also focusing on Kim Kiyoung's film on women and the four genealogical categories Kim crafted for his work --下(class), 火(desire), 蟲(insect), and 惡(evil) --, this paper will try to understand the East Asian woman's experience in modern society and see how the private pains, fears, anxieties, and desires of individuals intersect with the spurious success story of national economic and social development, as well as the integrative and disintegrative aspects of such experiences in post-colonial Korea and post-war Japan.

\section{Sons of the Empire}

"Frankly and certainly, I feel nostalgia for Japan's superior culture. After liberation, I tried to get to know Japanese films through smuggled film magazines...I also could get to know about unrated films and read Japanese film scenarios through that magazine (Kim Kiyoung).",

Kim Kiyoung was born and raised in colonial Seoul in 1919 (or 1922, Kim asserts) in an upper-middle class family, and moved to Pyŏngyang in the third grade of elementary school following his father's transfer. He graduated from Pyŏngyang Middle School in 1940, but after failing the entrance exam for Sebŭransŭ Medical School (formerly Yonsei Medical School), he moved to Kyoto and spent three years preparing for medical school there. ${ }^{9}$ He said that he watched many films during this period. He

8 Yu Chihyŏng, Yisip nyŏn kan ŭi taehwa [Conversation for Twenty Four Years] (Seoul: Sŏn, 2006), 49.

9 His testimony about his own experience in the imperial center during this time, however, is quite dubious, although it is widely known that he spent several years 
came back to Korea after liberation from Japan in 1945 and was admitted to Seoul National University School of Dentistry. During this period, he participated with a modernist theatrical group. But as soon as the Korean War (1950-1953) broke out, he moved to Pusan, where he started a new career as a documentary film director in the USIS (United States Information Service). It seems that he acquired the necessary knowledge and techniques of filmmaking at the USIS since resource limitations forced him to work almost as an independent film director, performing almost all of the tasks of filmmaking such as writing scenarios, shooting, lighting, recording, and editing. He recalled that the USIS was his film school. ${ }^{10}$ But he always emphasized that his influences in film style or aesthetic taste came from Japan or the West experienced through Japanese theater. The three years he spent in Kyoto in his early twenties seem to have been the critical time in which he formed his own aesthetic taste, admiring Osanai Kaoru, for example, a leader of the new theater movement in Japan. $^{11}$

He emphasized the avant-garde film watching experience in 1940s Kyoto, especially German expressionist films, as those were the only foreign films available during the Japanese wartime (1937-1941) and since Japan prohibited the screening of Hollywood movies after the attack on Pearl Harbor. As noted in the citation above, even after liberation and despite the political and cultural barriers between Japan and Korea, Kim tried very hard to keep up with Japanese films through reading smuggled magazines. Although he did not have frequent chances to watch Japanese

in Japan.

10 Yu Chihyŏng, Yisip nyŏn kan ŭi taehwa, 24.

11 While I did my research on his testimony, I discovered that Kim Kiyoung actually lied that he had chance to get lessons from Osanai Kaoru. It is impossible because Osanai Kaoru died in 1928. Regarding this lie and the desire behind his lie, see my unpublished article. Chungkang Kim, "Kim Kiyoung's Imperial Experience and Post-Colonial Filmmaking," presented in the Joint Conference between Research Institute of Comparative History (Korea) and Sinica (Taiwan) held at Hanyang University, May 11, 2018. 
films, he said he was impressed by film directors such as Oshima Nagisa and Nakahira Kō, the Japanese post-war new wave directors. Also, if there were any chances to visit Japan, he spent his time watching foreign and Japanese films as much as he could. For example, he went to Japan in 1961 to shoot The Sea Knows, and spent every weekend night in an overnight theater watching films. ${ }^{12}$ From his avid love for Japanese culture, although Kim Kiyoung could be regarded as belonging to the first generation of filmmakers in post-colonial Korea, his cinematic world appears to have been 'imperial' or 'transnational,' manifesting a psychological desire toward the imperial cultural center, even in a post-colonial situation. While most Korean filmmakers deny or keep silent about their colonial experiences, Kim was one of the few people who honestly talked about his 'nostalgia' for the imperial (or colonial) era, exhilarated by the modern experience of film-viewing at the center of the Japanese empire. Kim was also unique in that he did not apprentice under the older generation of Korean directors making films during the colonial period. His persistent and eccentric exploration of woman, gender, and sexuality in the process of the Korean peoples' entry into the modern world, then, strongly pertains to his own personal transnational life trajectory and his inclination to attach himself to modern Japanese culture.

Imamura Shōhei, in comparison, was also born into an upper-middle class family in Tokyo in 1926. He studied Western history at Waseda University and started his career at Shochiku Studio. As Kim Kiyoung, Imamura in this sense had a privileged class and educational background in Japan. The Japanese filmmaking system had already been well established by its first generation, and Imamura was the first of the younger filmmakers to formally defy the first generation of Japanese film directors. He especially criticized Mizoguchi Kenji, who was known for his sensitive portrayals of women, albeit in a more or less traditional sense. ${ }^{13}$

12 Based on his words, he watched Simón Del Desierto(1965) by Luis Buñuel in Japan.

13 David Desser, Eros Plus Massacre: An Introduction to the Japanese New Wave 
Imamura thought Mizoguchi arbitrarily constructed a non-existent beauty of Japanese woman via a fixed norm. To Imamura, 'Japanese-ness' was far more complex than Mizoguchi showed, and he claimed that "selfsacrificing women like the heroines of Naruse Mikio and Mizoguchi Kenji don't really exist...My heroines are true to life -just look around you at Japanese women."14 Although he was also trained under the Shochiku system, Imamura acted like an independent artist, writing scenarios, shooting, and editing, and he created Japanese female characters who were "true to life." In this vein, it is not strange that his camera eye can be described as "anthropological" 15 and less systematic. These two unique directors belonged to the same generation and shared a similar experience in learning their craft, and both challenged the given norms.

\section{Two Insect Women: 下(class), 火(desire), 蟲(insect), 惡(evilness)}

Both directors' The Insect Woman films meticulously explore the precarious nature of women's life in post-colonial Korea and post-war Japan respectively, and women's ways of structuring their own stories and feelings. In Imamura's The Insect Woman, the heroine Tome represents a woman from a poor family. Her life trajectory is juxtaposed with the narratives of modern history of Japan, parading through historical events such as the Pacific War, the American occupation, and the birth of a new nation-state. By contrast, in Kim's The Insect Woman, Myŏngja is a daughter of a concubine and more strictly concerned with her individual fate. In the end, she becomes a concubine of a rich but sexually impotent

Cinema (Bloomington: Indiana University Press, 1988), 110-111.

14 Donald Richie, "Imamura Revisited," Film Quarterly,63, no.1 (September 2009): 46.

15 Desser, Eros Plus Massacre: An Introduction to the Japanese New Wave Cinema, 122. 
man and used by the primary wife as a surrogate who is exploited to produce a male heir to the family. The representations of men either foreground women's lives or are marginal to them. The Insect Woman's female protagonists in both versions could be viewed as illustrating the life struggles of East Asian women, born to an incapable father (Imamura) or to a concubine and becoming one (Kim), and yet also trying to attain social mobility. Animalistic and primitive desires and difficult feelings about living according to bourgeois values characterize both women's struggles to attain social mobility. The trans-generational nexuses defined by individual gendered and classed social pathways aptly displays that social mobility exists in between and betwixt the discourses of individual mobility and national history.

Both films are very conscious of the barriers to class mobility that the women of modern Japan and Korea strove to overcome, while almost invisible in modern nations but which nonetheless rigidly define the social structures. However, these two films also reject easy demarcations such as "middle class" and "working class." Class definitions constantly shift and thus become precarious. Likewise, although the films do not follow fixed norms of masculinity and femininity, they portray class as also gendered and each film presents an essential picture of patriarchy as an oppressive power manifested in actions against women. Nonetheless, patriarchy does not merely reflect the fixed norms of East Asia either. The father in Imamura's work is mentally challenged, while the Korean father is sexually impotent. Each lower-class female protagonist, although seemingly located at the bottom of the social ladder, has the strong desire and power to make their own upward mobility possible. These women do not fit in with the stereotypical imagery of the "victimized woman" or "bad woman" as typified in the objectifying gaze of males.

These films also provide numerous examples of both men and women employing various strategies to survive and show how gendered demarcations in traditional or modern East Asian society do not remain fixed. For example, to perform like a virgin to get more money from her client, a Japanese prostitute uses cat's blood. In this specific scene, we see that a 
woman's community is formed around her and, as their communal relationship becomes stronger, it takes on the characteristics of a matrimonial society. Similarly, when Myŏngja wants to become a concubine, a gang of bar girls assist her by visiting her mark's house, destroying the expensive antiques of the household, and physically threatening the man's family. Modern medical technology also assists in fulfilling a concubine's desire to produce a male heir. The stories shared by Tome and Myŏngja may be patterned as follows: A woman overcomes class (下, the character read "ha" in Korean and "ka" in Japanese, meaning "lower") and gender disparity with their strong desire (火, read "hwa" in K., "ka" in Jp., meaning “fire") to fulfill their own primitive and animalistic instincts (蟲, read "ch'ung" in K., chū in Jp., meaning "insect").

Despite all these similarities, Kim's The Insect Woman ends with the psychosomatic killing of Myŏngja herself, a male heir (in fantasy), and a husband, while Imamura's insect woman shows more resilience in life. The Japanese movie ends with an almost propaganda-like harmonious farming village and her daughter living in the countryside. Although we know that Tome's daughter will most likely continue to face poverty and oppression and that her grandchild will be born into a similar circumstance the heroine faced, the visual presentation itself is quite optimistic. All the eccentricities that Kim and Imamura shared with one another diverge in this moment, when Kim's film judges woman as evil (惡, “ak" in Kr., "aku" in Jp.). The desire to continue the lineage of the man's family becomes vicious when a man's beloved baby is discovered frozen in the refrigerator and the woman suddenly is rejected by the man. The sadistic ending displaying the hideous scene of the protagonist slitting her own wrist and neck in Kim's The Insect Woman provokes unimaginably sharp pain and frustration in the viewers. This difference in the denouement or in the director's styles in presenting their stories might be related to the gap between the production time of these two films or genre conventions. However, such differences also compel the viewer to ask what happened in post-colonial Korea and post-War Japan that allowed one film to lead to cacophony while the other embraces harmony? 


\section{Vicious Desires of Kim Kiyoung}

This difference could be aptly framed in the asymmetrical relationship between Japan and Korea in the post-War and post-colonial situation. Koreans experienced 30 years of military dictatorship until the 1990s, while the Japanese were able to live under a US-sanctioned pacifist democracy despite the thorny episode of US occupation. In its simplest sense, it could be said that the grotesque and sadistic ending of Kim Kiyoung's film could be the reflection of dark 1970s Korea. Certainly, Kim Kiyoung's claustrophobia as well as his pessimistic touches such as the terrible end of the film's male heir, frozen as a giant ice cube in a refrigerator, could be metaphors for the lived experience of Koreans under the Park Chung Hee dictatorship. In contrast, Imamura Shōhei's optimistic ending could be read as a sign of a new nation that had just escaped from the trauma of total defeat and conquest by a foreign nation. It promises the bright future for the hetero-normative couple and a baby, and all the disturbances of a poor woman's life seems to be removed from the scene.

However, a doubt still remains in this neat answer, since an uneasy feeling for the fate of the insect woman who lost resilience in life in Kim Kiyoung's film makes us ponder about the situation of post-colonial people, another layer of hidden time that ghostly reappears in South Korean's minds. A closer look reveals the major difference between these two films perhaps lies in the way the woman's presence is located in the story. While Tome's presence is located in the grand national historical narrative, Myŏngja's experience is not attached to an actual historical time. Viewers only can assume that she is in the present time (1970s South Korea) with an ambiguous familiar lineage. Myŏngja is basically an allegorical character, and her new family cannot produce an heir. The whole story is frozen in the present allegorical moment like the frozen baby in the refrigerator. Kim Kiyoung's continuous attempt to find his own self through mimicry of Japanese culture could be symbolically interpreted as himself being presented as the son of a concubine with Japan being the 
patriarch. In this (psychoanalytic) scheme, Kim might see himself as the illegitimate son whose lineage cannot be formally acknowledged. The allure of modernity that brought Kim Kiyoung to the colonial/imperial setting did not set him free in the post-colonial situation. His obsession in creating a grotesque and foreign woman in South Korean culture was in a way a creation of a mirror image of the imperial counterpart, and thus had to be always shattered in the end. The difference of Kim's film from Imamura's, then, is something that cannot be neatly read only within the structure of dictatorship of 1970s' South Korea nor post-war Japan, but something that should be read as doubly-intersecting historicity. In the end, Kim Kiyoung's desire to bring out imperial culture from the lost memory of the post-colonial public can be described as a vicious desire that would never be welcomed in post-colonial South Korea. 
